\title{
Politics, Propaganda, and Prostitution of Literature
}

I

An article on Nigerian writing by Elechi Amadi, my compatriot, concluded thusly:

But when we would have had our say on corruption, injustice, and maladministration; when we would have dethroned foreign gods and reinstated ours, when we would have finally put black literature on that rung of the literary ladder where we think it belongs, what next? The future of Nigerian literature is inseparable from the future of the world literature which in turn is inseparable from the future of man. So we may rephrase the question: where is man going? When computers and robots finally take over the world and man faces a long dreary winter of mental apathy and physical inertia, will the novel have any part to play to save man from death through the atrophy of his mental and physical powers? Let us hope so.

Amadi's position as I understand it, and as it has been put forward by others I consider the founding generation of Nigerian literature in modern times, is that of an all-embracing humanism, a humanism which rejects all boundaries-national, racial, religious, and sexual. They insist that Nigerians, like all other Africans, belong to the family of human beings and must therefore make their marks against the backdrop of a global brotherhood. They ask such global questions as "Where is man going?" "Is man a mere 'mirror to annihilation"?" "Is there a future for man?"

Only a mad person would deny the genuineness of and the necessity for this attitude. But the questions which come to the mind of anyone who notes but refuses to work under this concept are many. For instance, why did this generation of writers go out of its way to tell the world, to mount a global rostrum to declare that there is a unity of human experience which cuts across political, religious, and racial boundaries? To answer this question, you must familiarize yourself with the beginnings of African literature in general and Nigerian literature in particular. The aim of most of the first generation of Nigerian writers was to tell the outside world, the "civilized" world of Europe and America, that, as Chinua Achebe put it, "culture did not begin with the coming of the white man to Africa." Achebe further disclosed that one reason why he wrote his novels was to 
show that writers such as Joyce Cary who attempted to depict African characters in their novels did not do justice to these characters and that he, being African, could, in fact, do much much better, and he saw it as part of his duty, his mission, to represent these African characters to the same people who had read Joyce Cary and Joseph Conrad. Amos Tutuola, whose first novel, The Palmwine Drinkard, was published in 1952, had this to say in a recent interview about the beginnings of his writing career: "I had read and saw the film of A Thousand and One Nights. I liked and enjoyed it. It reminded me that we have such stories in Yoruba culture and I wanted to write to show that we too have such stories."

It will be obvious from the above that the preoccupation of the first generation of writers in Nigeria had nothing to do with what was going on in their country, it had nothing to do with the realities of their own daily life. This preoccupation had consequences in the choice of language, the place of publication of their work, the expected readership, and the narrative technique which they were to employ in their novels. But these consequences will be dealt with later. To carry on with the questions which the preoccupation of our first generation of writers with global humanism raised: What did they hope to achieve with this global humanist attitude? I think this is a straightforward question. If they proclaimed themselves the mouthpiece of a global humanism, it would be a totally prejudiced non-African who would have the courage to deny that Africans belong to this global family of man. With this admission they would have won their point.

As mentioned above, the implications of the primary aim of their writing had important effects on the critical attitude one must take to their work. As far as language was concerned, they were addressing themselves to outside, European-languages-speaking Europeans and Americans. So, without doubt, they wrote in the European languages with which colonialism had tortured the minds of Africans. Many of them, including Chinua Achebe, went to great lengths to excuse the use of English and French in their works. One would have thought that given the aim of their writing, it could be assumed that they would use the language of the colonial powers to address them. But this was not the case. Conference after conference of African writers on African writing debated and argued the language question ad nauseam.

Another implication of the aim of this writing, geared towards educating outsiders about Africa, was the choice of a place of publication. Chinua Achebe took his manuscript with him to London in 1956. In 1951, Amos Tutuola had sent his own manuscript to Faber and Faber in London. Yet there existed at that time in Nigeria possibilities of these budding writers being published locally. The now famous Onitsha Market literature was already in existence. Cyprian Ekwensi, one of the most successful and popular writers in Nigeria, who belongs to the first generation of Nigerian 
writers, had his first works published in Onitsha and distributed in Nigeria. I read one of his first novellas, She Died in the Bloom of Youth, when I was in secondary school class two (1958). The Onitsha Market publishing venture had started as far back as 1946, and Tabansi Bookshop, the publishers of Ekwensi's novella, had many other titles under its name. Yet, somehow, these budding writers did not seek publication at home.

A third implication of their aim was that of the narrative technique, which tended to be blatantly informative in the course of their novels. The third sentence in Amos Tutuola's Palmwine Drinkard does a quick informative jig which characterizes the whole novel: "In those days we did not know other money, except COWRIES [sic], so that everything was very cheap," etc. Any Yoruba reader would know that the form of currency in Yorubaland before the white intervention in our history was the cowry shell picked at the seashore. But then Tutuola was not writing for the Yoruba reader. Perhaps the most guilty of this disturbing narrative formula is Onuora Nzekwu, author of Wand of Noble Wood, Blade Among the Boys, and Highlife for Lizards. In his Blade Among the Boys, he spends paragraphs and sometimes pages to explain particular words from his own first language, something that would not be necessary if he was addressing his own people. "Occasionally the cow Fulani came to town. Invariably they came for sharo, a flogging custom which was a facet of traditional marriage among them" (p. 13). One can quote other examples, even from better writers than Nzekwu such as Chinua Achebe and Elechi Amadi. But of all those who used their novels as vehicles of carrying information to the uninformed of Europe and America, Chinua Achebe may be the only one who uses the information as part of the action of the novel rather than merely an inserted piece of anthropological data.

I must emphasize at this point that I do not see anything wrong in the action of this first generation of writers. It was true and still is a fact that Europe and America were and are ignorant of Africa and the African way of life. Like the négritude movement of the French-speaking areas of Africa, this "teach-in on Africa" literature served its historical purpose. And it has been successful, with the effect that within a quarter of a century (19521974) some of the misconceptions about Africa and the black man in the minds of Europeans and Americans have been questioned. Of course they still exist, if only as spooks, but that is another matter altogether. So if one took their work in a historical perspective, this first generation of Nigerian writers has rendered valuable service to the cause of literature in Nigeria and in Africa.

But I think that it is unfair for any writer from this group to lump together as "prostitution of literature" the attempts to address ourselves to younger writers as well as writers of the first generation who saw the need. And in 
making this charge I think that Elechi Amadi has not asked himself an important question, just as he has been misinformed on the work of Wole Soyinka. In his presentation Amadi claimed that "a novelist [who] feels strongly about a political issue should simply write a dissertation on it. Soyinka did so in The Man Died, and I did so in Sunset in Biafra. Both books are non-fiction and describe the Nigerian conflict from various viewpoints."

The fact of the matter as far as Wole Soyinka is concerned is that Soyinka has written what he terms the War Quartet. The titles of the books in the quartet are Madmen and Specialists (a play), A Shuttle in the Crypt (a collection of poems), The Man Died (diaries kept in prison), and Season of Anomy (a novel based on the civil war in Nigeria). The play, Madmen and Specialists, about a young doctor lately returned from the wars, deals with what the playwright calls "a problem in my own society, the betrayal of vocation for the attraction of power in one form or another." Season of An$o m y$, a novel and the last of the quartet to be published, describes the activities of a group of politically conscious young people to bring back hope to a land bereft of a new tomorrow. A Shuttle in the Crypt is a collection of poems dealing with Soyinka's experience before, during, and after his imprisonment and the civil war. So it is not quite in line with the facts when Amadi claims that Soyinka opted for the easy way out of using the day-today problems of the nation as material for fiction.

Now the big question, which I think the advocates of this global humanism fail to ask, much less attempt to answer, is this: Where along the line does identification with global man stop and self-identification begin? Take the situation of the achievement of America in space. America has sent man to the moon. As a man I should identify with such a momentous step taken by Man. But America has also been in Vietnam, has interfered vigorously in the attempts of other people to lead their own lives in their own ways. Do I identify with this as well since it is the same wealth which sent Man to the moon which also sent Americans to Vietnam?

It would be appropriate here to quote one of the most important American writers I have read, Ralph Ellison, author of Invisible Man:

Too many books by Negro writers are addressed to a white audience. By doing this the authors run the risk of limiting themselves to the audience's presumptions of what a Negro is or should be; the tendency is to become involved in polemics, to plead the Negro's humanity. You know, many white people question that humanity, but I don't think Negroes can afford to indulge in such a false issue. For us the question should be, what are the specific forms of that humanity, and what in our background is worth preserving or abandoning. (Writers at Work: The Paris Review Interviews. Second Series, 1963, p. 323.) 
African writers are not just writers alone. They are also social and political figures in their society. Leopold Sedar Senghor, one of the founders of the négritude movement, is and has been the President of the Republic of Senegal since 1958. David Rubadiri of East Africa was for some time his country's ambassador in the United States. J. P. Clark in his book of poems Casualties (poems emerging from his experience of the Biafran war in Nigeria) claims friendship with the head of state of Nigeria. Elechi Amadi is the permanent secretary in a ministry in the Rivers State of Nigeria. T. M. Aluko, creator of the comic character of Royanson in his first novel One Man One Wife, was, until recently, the Minister for Finance in the Western State of Nigeria. These few examples will show that African writers are not simply writers in their society. They occupy very important positions in the social, economic, and political affairs of their countries. How then can these people avoid issues of the day? How can they, involved as they are with everyday problems of their country, refuse to write about their experiences except by deliberately taking the ostrich posture?

In other countries of Europe and America, writers, artists are considered outsiders, refugees within their society, and even if a few of them are close to positions of power and authority it is by chance and it is possible they cannot really exert any pressure on the power process.

What is important in all this is the fact that these countries already have systems which guide their societies in their everyday life; they have yardsticks against which rulers can be measured, scales on which their leaders can be weighed, and if they are found wanting, the system has the mechanism for dealing with them. So writers here are not involved in bringing about a system by which their society must exist. They can therefore afford to "evade the island" and can indulge in the luxury of art for the sake of art or for mere therapy of the nerves. We on the other hand who live in the so-called Third World cannot afford this luxury. In Nigeria, we live in a society where the old order has been destroyed and the new order has not even been chosen, much less formulated and brought into the system of running a modern society. Things of old have fallen apart and the new things have not yet been brought together. We are still in the process of picking up the bits and pieces to build something new and enduring. Most African writers come from the best educated group in their countries. They have, most of them, been educated at public expense. They therefore owe the society something. They are involved, and should be, in getting things to move smoothly in these countries. They have not refused to play their parts, play their roles in the process of nation-building. How then can they avoid the particular and embrace the general?

We have a commitment to educate our people. We also need to create myths for ourselves. This is a historical duty. Writers in other lands have 
had to play this role at one time or another in the history of their own countries. Dickens in Britain, Victor Hugo in France, Maxim Gorky in Russia. This historical duty is temporary. Another generation of writers will come and they will feel free to pursue their personal dreams and feelings. Just as we of the new generation are now able to devote ourslves to addressing our own people because the pioneers of African literature addressed themselves to Europe and America, the generation of writers to come will be able to afford the luxury of art for art's sake because somebody else has taken the step to deal with a historical situation which had to be dealt with. I have already quoted the black American writer Ralph Ellison. I would like to give the opinion for what it is worth that the reason why race is still an important issue in black American literature (either a writer avoids it, like Frank Yerby, or makes it the center of his work, like Imamu Baraku) is because nothing much has been done towards changing the social situation which Richard Wright and Ralph Ellison dealt with in their novels Native Son and Invisible Man. As soon as something is done about the social situation which these writers have tackled in their works, black writers can then move to new fields and show new strengths.

It would also be interesting to speculate on the state of literature in England in the last five years or so. Why is it that no particularly important writer has come out of England recently? Note that I say "important," not "talented." Is it not because writers in England have become more and more personal and have tended to write about form, thus exemplifying the image of the snake feeding on its own tail: a painful process of self-destruction? Would it be that, to most English writers, there is nothing particularly wrong with society, everything is all right, and so they have had no cause to champion, no defined goal to sharpen the points of their pens, to inspire them to new heights?

"Prostitution" in the way it was used by Elechi Amadi would mean "the sale of one's talent to an unworthy cause." Is it an unworthy cause for a writer to call the attention of his society to the problems which plague it? Is it an unworthy cause for a writer to attempt to resolve within the framework of fiction the tensions which afflict his society? Would it be called an unworthy cause for a writer to try in his own little way to return some of the gifts of his education to his society and help it along the path of stability and self-realization? Obviously, for me these are rhetorical questions.

\section{III}

I will end by trying to show what the effect of a new generation of African writers has been on African literature.

We have come to the point where it is necessary for critics of African literature to start subdividing the continent into geographical writing regions. For some time there have been the three main divisions: West Africa, 
East Africa, and South Africa. Not much was known about North Africa and so it did not form part of the literature of Africa. Now we have to talk of Nigerian literature, Ghanaian literature, Kenyan literature, etc. This is one consequence of the new generation of writers. The world knows the names of such Nigerian writers as Wole Soyinka, Christopher Okigbo, and Chinua Achebe. But the same country has been able to support and nurture new talents, names unknown to the culture vultures of the West. These writers have made and are making their reputations within Nigeria, and if they have been heard outside the country, it has been by outsiders who had to lean over the fence and find out what was going on. Like our raw materials, we used to take it to them at their own price.

To begin with, there is Ola Rotimi, a playwright attached to the University of Ife at Ile-Ife. Ola Rotimi is the author of The Gods Are Not to Blame, Kurunmu, and Overawmin. One of his earliest plays, which has been produced in the United States, Our Husband Has Gone Mad Again, remains still unpublished. Ola Rotimi's plays have been produced in Nigeria and enjoy a great measure of popularity. Ola Rotimi himself enjoys the reputation of being one of the most inventive directors we have had in Nigeria. He directs the first professional university-based theater in Nigeria and possibly in Africa.

There are other playwrights, such as Mrs. Zulu Sofola, whose Wedlock of the Gods has been produced in the United States, and Rasheed Gbadamosi, whose radio play Trees Grow in the Desert landed him in jail for a fortnight.

There is the young poet Femi Fatoba, who has published mainly in journals and is now looking forward to his first collection of poems. There is Femi Osofisan of the University of Ibadan, whose main production has been poetry, though he has recently published two extracts from a novel called Kolera Kolej in a university journal, New Horn. The novel is to be published soon in Nigeria. From the reaction generated by the extracts, it seems something worth looking forward to.

These are a few of the names which the outside world will not hear of in a hurry.

All the writers mentioned above are being published in Nigeria. This publication in situ has been one of the results of the new generation of writers. Publication overseas is no longer considered as prestigious as it used to be. Of course these writers can still be published overseas, but this is after they have been exposed first and foremost to their home audience.

Another result of the new generation of writers is the almost simultaneous development of African critics of African literature. Little by little names such as Abiola Irele, Ime Ikiddeh, and Peter Nazareth became known and a particular critical stance is developed, a stance which critics of nonAfrican origin will have to understand before they can presume to make 
final pronouncements on the writings of Africans. Such western critics as Gerald Moore and Ulli Beier are known as critics of African literature. These names will have to go along with the first generation of writers whom they helped to attain world-wide recognition. The first generation of writers will have to be reassessed by this new breed of critics and the contribution of these writers recorded and accorded its proper place in our literature.

The implication of all these facts is that the foreigner interested in African literature is no longer going to have it delivered to his doorstep. He'll have to come out to us and get it, just as I would come to the United States to get the books of Chester Himes or Frank Yerby because this is where these books are. Naturally this is good for our economy and also for our ego!

Perhaps the most important result of this new generation of writers is the growth and development within Africa of a reading public. This is good for us, and one hopes that it will continue to grow and develop.

I wish to conclude on a note of personal affirmation: right now there are historical circumstances which make me and a number of other writers in Nigeria feel that we can look at such phrases as "political propaganda" and "prostitution of literature" as deliberate concessions made to the West by escapist writers among us. The historical circumstances in countries are naturally different. So you will write differently. In the long run, your treatment of the lot of Man in your country and my treatment of his lot in Nigeria will all add up to the treatment of the lot of universal Man in our time. By looking closely enough and truthfully enough at ourselves, we also look at mankind.

\section{LUIS DOMINGUEZ / CHILE}

\section{A Still Unmanageable Language}

Literature is primarily language. The writer's obligation is to rebel against the old tongue and re-name things. But language is like blood in culture, and in cultural evolution there are no leaps in the dark. We rebel against a tradition when we have previously assumed it as ours. Thus, rebellion in language is also a consequence of feeling it as one's own. For us, coming from a colonial system, the order of the relation between language and things begins transposed: Castilian in Spain designated existing things; in Spanish America it pre-existed the things. The conquerors imposed a 